Island Studies Journal, Vol. 11, No. 2, 2016, pp. 521-536

\title{
The transformation of island city politics: The case of Macau
}

\author{
Li Sheng \\ Department of Government and Public Administration \\ University of Macau, Macau \\ edmundsheng@umac.mo
}

\begin{abstract}
This paper focuses on the island city of Macau as Europe's last Asian colony and one of China's special administrative regions (SARs) that enjoys a high degree of autonomy. The author traces the root cause of the current social discontent and political dilemma in the face of Macau's post-colonial casino boom and economic miracle. The study finds that Macau's islandness, smallness and geographic location significantly affect the island city's urban political culture. While Macau shares similarities with other island cities across the world, as a Chinese casino city under Portuguese administration for more than 400 years, certain unique features have also developed.

Keywords: islandness, casino, China, consensus politics, informal politics, Macau, island cities

(C) 2016 - Institute of Island Studies, University of Prince Edward Island, Canada.
\end{abstract}

\section{Introduction}

In the emerging field of urban island studies, there has thus far been little research into the political cultures of island cities. This paper explores the political development of the urban archipelago of Macau in order to consider how densely populated island status may affect political culture.

Macau SAR (Special Administrative Region) is an exceptionally autonomous subnational island jurisdiction of China. Macau's colonial history has granted it a number of Western-style formal democratic institutions, yet these are combined with a conservative Chinese political culture. This paper begins by setting forth Macau's historical background and then describes and analyzes the more recent development of the island city's political culture.

Grydehøj (2015) noted the benefits of island spatiality in establishing a government and trading post. In particular, he emphasized territoriality benefits, which enable foreign elites to project power outward, defence benefits, which protect power holders from external military threats, and transport benefits, which make strategically located small islands ideal for port industries. Europe's Asian colonies expanded rapidly around China beginning in the $16^{\text {th }}$ century, and they were almost all small islands that aimed to benefit from the huge Chinese market while maintaining western governance and lifestyles. Because of their land scarcity and island spatiality, all these islands developed prosperous but densely populated cities. From the mid- $16^{\text {th }}$ to the early $19^{\text {th }}$ century, Macau was the most prosperous port of transshipment in the Far East. It was a hub for merchants, missionaries and immigrants from Europe, Asia and the Americas and served as a meeting place for Eastern and Western religions and cultures. Steyn (2015) observed the mutual attraction, co-existence and synthesis of cultures in Mombasa, Zanzibar and Goa. Similar phenomena could also be observed in Macau, i.e., people from all sorts of cultural backgrounds gathered together in the island city, molding a 
cosmopolitan crossroads, and different ethnic groups, religions and cultures harmoniously interacted. The rise of Shamian in the $19^{\text {th }}$ century as concessions to the UK and France, Qingdao as a concession to Germany, and Gulangyu, where 13 countries enjoyed extraterritorial privileges, undermined Macau's outstanding position. In particular, the rise of neighbouring Hong Kong in 1842 as a crown colony with a deep-water harbour, an even better geographic location and transport links ultimately ruined Macau's position as the power center for westerners in Far East (Grydehøj, 2015). To survive, certain anomalous industries, such as gambling and coolie and opium trading, began to develop in this then economic backwater.

Although traditional craft industries, such as matches, fireworks and incense, prevailed in Macau in the nineteenth century, the enclave witnessed an early phase of industrialization when a number of rudimentary textile industries with little machinery application began to develop in the first few decades of the twentieth century. In the 1950s, modern light industries, notably textiles, were established by investors who were attracted by Macau's duty-free privileges. Macau then entered a phase of industrial growth when increasing numbers of modern factories and local businesses shifted from serving the local consumer economy to export-oriented manufacturing. In the 1990s, the economic growth slowed and began to shift to the manufacture of artificial flowers, toys, electronic goods, ceramics and leather goods, largely because of the rise in textile manufacturing in the Chinese coastal regions (Huang, 1999).

The gambling industry, which was legalized in the island city in 1847 , underwent a major transformation in the 1960s. After being granted an exclusive gambling license in 1962, the Sociedade de Turismo e Diversoes de Macau (STDM) introduced western-style games and modernized the marine transport between Macau and Hong Kong to attract more visitors. Construction activity also increased in the 1980s, mainly due to the thriving demand for commercial property and major public sector projects. The industrial expansion and resulting rapid growth in trade and output during the 1970s and 1980s generated strong demand for services, particularly banking. The urban expansion of the late 1970s and early 1980s has been cited as resulting from the intense economic growth that laid the foundation for Macao's modern economy (Lau, 2002).

Macau has been experiencing rapid economic growth since its handover to Chinese sovereignty in 1999. With a double-digit annual economic growth rate between 2002 and 2014, Macau has become one of the richest island economies and the world's largest casino city, with GDP per capita increasing from US\$ 14,258 in 2002 to US\$ 89,333 in 2014 (Sheng and Zhao, 2015). Macau's economic success is largely a result of its decision to liberalize the previously monopolized gaming industry to allow foreign operators in 2002 and China's Free Individual Travel (FIT) scheme, implemented in 2003, which allows mainland Chinese in the rich coastal provinces travel to Macau using a simplified procedure (Sheng and Tsui, 2009a).

Macau's boom has been praised as a "great success" of the "One Country, Two Systems" idea, which emphasizes the smooth decolonization and formation of the SAR; yet, serious economic, social, environmental and political side effects have emerged. Over the past decade, there has been growing social discontent challenging the SAR government's development strategy and its implications for Macau's local community. The resulting political instability could be observed in a series of violent street protests against the government's public policies from 2006-2008. The demonstrators vented frustrations that had been steadily building since the overheating of the gaming sector. The protests highlighted the 
huge gap between the rich and the poor, the plight of jobless locals and the need to share the benefits brought about by the casino boom (Sheng and Tsui, 2009b).

Macau's dilemma of social discontent amid an economic miracle has attracted increasing attention. While a good deal of this attention has been paid to the post-colonial casino boom driven by foreign investment and its impacts on the host community, most studies view the casino sector as contributing to local socioeconomic development. A number of tourism and geography studies, however, have focused on the negative externalities of the overgrown tourism sector on the small island economy. Nevertheless, these studies tend to discuss isolated issues, and little attempt has been made to link the discussion with islandness and smallness and to the broader geographic context (Sheng, 2011a; 2011b). The relative importance of this issue and the paucity of related literature motivated the author to conduct the research presented in this paper. Attempts have been made to trace the root causes of the current dilemma in Macau by analyzing governance capabilities, citizen participation, consensus politics, and formal and informal institutions in the context of an island city socialpolitical culture by referring to the urban islands studies literature.

\section{Evolution of Macau's island city political culture}

This section provides an overview of the historical development of Macau's political culture. The island city's population development is examined, and a comparison of the Macau SAR's institutions with those of Hong Kong and Singapore is also presented.

\section{Territorial and demographic development}

Macau's territory has gradually been enlarged as a result of continued land reclamation. Prior to the Portuguese colonization in the early part of $15^{\text {th }}$ century, an area of $2.78 \mathrm{~km}^{2}$ was recorded for the island city. With the annexation of Coloane and Taipa Islands in the mid-19 $9^{\text {th }}$ century, the Portuguese enclave increased to $10.28 \mathrm{~km}^{2}$ (Huang, 1999). Since then, the island city has undertaken massive land reclamation from the sea. The previous Macau Island became Macau Peninsula, a $4.5 \mathrm{~km}^{2}$ Coati Strip emerged connecting Coloane and Taipa Islands, and the ongoing reclamation of the sea northeast of the Macau Peninsula will create another $4.5 \mathrm{~km}^{2}$ island by 2019 . Currently, the Macau SAR has a territory of $32.8 \mathrm{~km}^{2}$, and the newly acquired $85 \mathrm{~km}^{2}$ sea territory from China indicates that land reclamation may be accelerated in the future (Macao Statistics and Census Services, 2015).

With its economic booms and busts, Macau's population has also experienced up and down movements throughout the history. When the Portuguese first established the island city colony in 1558, there were only 800 inhabitants in Macau, including 600 Portuguese. The island city experienced an economic boom, attracting thousands of immigrants from all over the world. By 1640, the population had increased to 40,000, including 6,000 Portuguese, 29,000 Chinese, and 5,000 of other nationalities. In the face of fierce competition from other European colonies around China, the island city fell into an economic downturn in the first half of $19^{\text {th }}$ century. A population of 13,000 in 1842 , including 6,000 Portuguese, reflected the retreat of the previous power center for westerners in the Far East. With the rise of its gambling sector, however, Macau was revived, and it recorded a population of 74,866 in 1910 (Huang, 1999). The city became more and more Chinese after the Opium War, and the percentage of Chinese has been over $90 \%$ of the total population since the beginning of the $20^{\text {th }}$ century, although the Portuguese continued to govern the island city until 1999. 
Macau's population has been experiencing rapid growth since the 1980s, mainly because of refugees from mainland China before the handover and imported labour and immigrants via investment or professional schemes after the handover. Today, the small island city accommodates a population of 649,100 , of which $1.5 \%$ are wholly or partly Portuguese, $6.8 \%$ are of other nationalities, and the rest are Chinese. It is noteworthy, however, that more than 100,000 Macau Chinese are holders of Portuguese passports, making them in effect Portuguese citizens. Also noteworthy is that $60 \%$ of Macau's total population was born outside the island city. This group is predominantly of mainland Chinese origin (Macao Statistics and Census Services, 2015). Although Mandarin Chinese is the official language of Macau along with Portuguese, over $85 \%$ of the population speaks the Cantonese Chinese dialect, and the government's working language is in effect Cantonese.

Anckar (2006) found that most island states are microstates with less than one million inhabitants. Although Macau is a sub-national jurisdiction, its highly autonomous political status, strong island characteristics throughout history to the present, and small size and population allow it to share a number of similarities with other microstates across the globe. Grydehøj (2016) noted that liberal democracy is commonly considered to be universally applicable at the national level or for highly densely populated regions that have been granted a large degree of autonomy. With over 20,000 people per $\mathrm{km}^{2}$, and having been granted many more political rights than any other federalist state, Macau theoretically seems to be ready to practice liberal democracy. In reality, however, Macau's islandness, smallness, political autonomy, immigrant dominance, and the huge influence of China jointly determine the island city's somewhat unique political culture. Therefore, analyzing the case of Macau in an island city context may bring about fruitful research findings.

\section{Comparative perspective on Macau SAR's institutions}

As China's two special administrative regions in the framework of "One Country, Two Systems", Macau and Hong Kong share similar characteristics but also differ in some ways. According to the Basic Law, both SARs have a high degree of autonomy in domestic and international affairs: they can keep their own tax revenue, dispose of fiscal reserves, and implement their own economic, cultural and social policies. Though foreign relations are under the jurisdiction of the central government, both SARs can exercise a large variety of diplomatic functions. With regard to government formation, the heads of the two SARs and all lawmakers are elected locally, and they must be permanent residents of the SARs (Leng, 2011). In practice, however, Macau is more dependent on Beijing than Hong Kong due to its tiny size and mono-economic structure.

From a bottom-up perspective, the two SARs enjoy a high degree of local autonomy, as evidenced by their public administration and cultural expression. English in Hong Kong and Portuguese in Macau were the official languages during colonial times and have remained so following the handovers. Mandarin and simplified Chinese characters have not replaced the Cantonese dialect and traditional Chinese characters as the working language. While in China local leaders are usually posted from other cities in order to prevent localism, only permanent residents of the SARs are eligible to serve as legislators and principal officers. In addition, a high degree of religious freedom is allowed in the SARs, which is substantially different from the restrictions on religious freedom in mainland China. Macau's period of Portuguese administration saw one-fourth of the population given Portuguese passports, almost all of whom were well-educated and wealthy Macau citizens. Beijing silently consents to dual 
nationalities for principal officers (Xu, 2013). In addition, all Macau and Portuguese laws continue to be valid after the handover. Portuguese remains the de facto official language in court proceedings, and the Macau Lawyers' Association, which oversees lawyer registration, continues to be dominated by Portuguese-speaking lawyers (Zhao, 2011).

Meritocracy guides the Singaporean style of governance, and the philosophy is that it considers the masses to be largely ignorant and benighted, and as such, they should be subject to the rule of the elite. On the contrary, the SARs' idea of government is based on the principle of positive non-interventionism, which gives impetus to the creativity of individuals and the private sector. Unlike the SARs, however, Singapore is an independent nation with a broader and clearer scope of power and does not need to spare too much time to address the complexities of the Chinese government (Ho, 2015). In Macau, in particular, though certain issues fall within the scope of power of the SAR, the SAR government still prefers to ask Beijing's opinions prior to decision making. While a small group of elites in Singapore use their superior knowledge to bring benefits to what they consider to be a largely ignorant and passive population, Macau's leading class is never considered to be superior leaders; instead, they tend to be humble and to listen to the masses.

\section{Pre-handover island city political culture}

Political culture can be divided into three categories: parochial-subject, subject-participant and parochial-participant (Ke, Konrad and Morath, 2015). The political culture across the different communities in Macau has evolved over time. Before 1984, the Macanese, as localized Eurasians, had a participant culture, whereas the Chinese community was characterized by a parochial culture. After the military coup in Portugal in 1974, democratic elections were allowed in the Portuguese colony as introduced by the legislature to provide a forum for citizens' political participation. Macanese actively participated in the elections, and the first two Legislative Assemblies (1976-1984) were dominated by Macanese who were involved in a power struggle with the Portuguese expatriates who led Macau government. Grydehøj (2016) noted the geography of democracy and the necessity of conceptualizing alternative forms of democratic governance. The post-revolution Portuguese government pursued democratization and decolonization of its former colonies, and different democratic solutions arose in different colonies and at different spatial scales. In the case of Macau, however, the democratization process had a high degree of decentralization and a largely decreasing degree of external control. The process predominately benefitted Macanese and to a certain extent represented negative impacts of the democratic discourse designed by Portuguese central government. While unsatisfied Macanese demanded more autonomy and even pursued separatism, the politically constrained Chinese masses are largely characterized by political apathy.

Chinese people were rarely involved in local politics, as the franchise was largely constrained and particularly discriminated against mainland-born Chinese, who made up a considerable portion of the total population. Overall, the Macau Chinese were apolitical, materialistic and refugee-minded at the time. This refugee mentality played an important role in forming the political culture. While some refugees longed to move elsewhere, most of them ultimately stayed on the island because of job opportunities. However, the refugee mentality persists, for instance in a tendency toward pragmatism and focus on economic survival rather than political engagement. 
The experience of refugee status and a different political context in mainland China may have prompted a degree of political passivity among the Chinese in Macau. They tended to accept the status quo in the hope that it would improve from above. Nevertheless, Macau's political system and culture was actually not friendly to refugees, who were underprivileged. However, in comparison to the refugees' previous lives in mainland China, they were largely satisfied with the island city. Fleeing from political turbulence, economic disaster and religious persecution, Macau provided them with a simple safety network and their basic needs, so they were thankful. Political indifference and docility may also reflect the dominant Confucius ideology in China, thus preventing people from tackling of issues relating to human rights, social inequality, justice and democracy. Chinese people were accustomed to living under a closed authoritarian or even totalitarian regime, and they did not feel that they should be vocal in political issues, which was something for the big men. On the other hand, as a flourishing free port, the living standards in Macau have been always far above the rest of China, so the docility also reflected overall satisfaction with the Portuguese colonial government and the Macau Chinese community leaders.

There were only a few directly elected mandates in the Legislative Assembly prior to 1984, and the Macau public generally lacked an understanding of democracy when Portugal began its democratization and decolonization process. Macau's 1984 political reforms granted 51,000 citizens electoral rights, most of whom were Chinese, and more than 29,000 ballots were cast by approximately $56 \%$ percent of the registered voters. The ongoing negotiations between Portugal and Macau over the island city's handover made well-educated Macau Chinese care about the future of the Chinese territory under Portuguese administration. Dozens of Chinese-dominated social groups were formed after 1985, including the Social Science Association, the Social Workers' Association, and the Post-Secondary Graduates' Association. The leaders of these interest groups were intellectuals who had a strong sense of belonging to the city and whose educational level exceeded that of most Macau residents. The increased political activity of Macau Chinese intellectuals during the 1980s indicated that a participatory political culture had emerged in the previously apolitical community (De Pina-Cabral and Lourenco, 1994).

Anckar (2006) found that islands are in general more prone than the mainland to pursuing democracy, plurality elections and direct democracy. Moreover, their small size adds to the general impact of islandness, i.e., they are more consistent than larger islands in the pursuit of these policy choices. Considering Macau's political development in the 1980s, the island city followed the democratization path of small islands based on the theoretical predications, and its adherence to parliamentarianism and support for direct democracy devices became obvious. It is worth mentioning, however, that the more educated Macau Chinese enthusiastically took part in the pre-handover democratization process, while the general political culture of the Chinese masses remained parochial, although more of them voted in the assembly election because of mobilization by the Chinese elite. The Chinese population of Macau still tended to be politically passive and was more attuned to the benefits that the government should provide than to how citizens might influence the government. This general culture impeded the smooth and steady democratization of the island city in the following years despite the engagement and optimism of Macau Chinese intellectuals.

The signing of the Joint Declaration of China and Portugal on Macau in 1987 paved the path to handover and also motivated Macau Chinese to contribute to the localization, decolonization and democratization process during the transition period. A subject political 
culture began to emerge in the island city after 45,000 illegal immigrants from mainland China became ordinary Macau residents through amnesty in 1990. Moreover, the adoption of Chinese as the second official language in public administration in 1991 made it much easier for Macau Chinese to participate in local public affairs (Xu, 2013). Furthermore, the establishment of the University of Macau in 1981 and the Macao Polytechnic Institute in 1991 helped to cultivate a more informed and independent young generation of Macau Chinese. Overall, the expansion of the middle class intelligentsia in Macau in the 1990s led to a corresponding increase in political participation.

Despite the significant improvement in the political culture in the island city, passive attitudes and orientations continue to play a major part in local politics. As the majority of voters in Macau during the transition period were elderly, poorly educated and new immigrants who had been organized to vote in the Legislative Assembly elections by the Beijing-controlled labour unions and neighbourhood associations, they were actually not interested in and could not distinguish among the candidates of different social groups who had different platforms. Largely in contrast to Hong Kong, the Portuguese colonial government did not train elite Chinese civil servants, so there were few qualified professionals in the government at the time of the handover (Song, 2015). While western-oriented Chinese intellectuals were anxious to see a democratic SAR in the near future, the Macau Chinese community leaders tried all means to convince the masses that it would simply be better to return to the motherland.

\section{Political developments in the post-colonial era}

The political environment in Macau changed after its handover to China in 1999 with the emergence of a Chinese-dominated SAR government. Veenendaal (2013) found that the specific dynamics through which microstate competition occurs strongly diverge from those of larger countries. On the one hand, increased homogeneity in island cities may be transformed into more consensual politics, which may foster democracy; on the other hand, the absence of ideological demarcations may lead to the elimination of competition. Indeed, consensus politics and a democratic structure without the same degree of democratic practice characterize the post-colonial island city governance in Macau. Veenendaal's prediction of the colonial legacy affecting post-colonial political institutions and culture is also evident in Macau, not only with regard to the organization and distribution of power and an electoral system stipulated by the largely Portuguese-style Macau Basic Law but also in terms of the government's actual decision making and electoral practices as well as the general perceptions of Macau's population in terms of politics. The findings from a 2001 survey showed that Macau residents generally held positive opinions about essential elements of western democracy such as equal rights, political participation, civil liberties and pluralist politics as guaranteed by the Basic Law, and they almost unanimously agreed with "One Country, Two Systems" and "Macau People Govern Macau" (Chong, 2015).

In 2002, the previously monopolized casino industry was liberalized to allow foreign investors. Macau's economy began to take off, with an annual economic growth rate of over $20 \%$ between 2004 and 2013. Social groups with casino backgrounds explicitly expressed their preferences in gaming matters to check the power of the government, even as their influence over the city expanded as the largest employer and taxpayer (Sheng, 2014). In the 2005 election, representatives of the gambling industry won half of the directly elected 
mandates in the Legislative Assembly and two additional seats through indirect elections by social, community, charity and sports interest groups. The gaming industry interest groups are obviously pro-establishment and are concerned about the proliferation of gaming facilities. Conversely, only three pro-democratic lawmakers supported a campaign to introduce a motion or made statements in the Legislative Assembly criticizing the government's labour policies that predominantly benefitted employers, which indicates that the working class in Macau does not have enough representative delegates in the Parliament (Chong and Chan, 2012).

As the working classes are unable to exert much influence on governmental decision making, instead of ordinary political participation, some of them have sought to challenge the government by participating in a series of street protests. The active participatory behaviour demonstrated in the protests has obviously increased political awareness and cultivated a prodemocracy consciousness among Macau residents. Some Macau locals tried to use petitions and signature campaigns to express their political demands or to alter certain government policies. The street protests that occurred between 2006 and 2009 have fostered enthusiasm for politics in Macau and in particular have made young people increasingly vocal, independent and supportive of political reforms (Lai, 2010). Nonetheless, most Macau residents have yet to develop an urgent need to use democracy as a means to check government power. Although social discontent exploded in the May 1 protests in 2006 and 2007, the government has not suffered from any serious political crisis resulting from public participatory actions.

The fierce competition in the 2013 Legislative Assembly election indicated an enormous increase in political participation. An unprecedented 20 political groups and 143 candidates competed for the 14 directly elected seats. Nearly 280,000 Macau residents registered as voters for the election, an increase of $80 \%$ over the 2001 election, and the turnout rate exceeded 59\% (Lo and Chong, 2016). One aspect that needs to be mentioned is the significant improvement in voter quality. More and more people voted in the election because they felt it was their civic duty and political responsibility to cast their ballots. Voters also cared more about the capabilities, public image and past performance of the candidates than their personal relationships (Lo and Yee, 2005). In particular, better-educated voters become participant-oriented and rejected the traditional values of political indifference, docility toward authority and social harmony, preferring instead a more open and competitive political environment.

Baldacchino (2012) argued that the likelihood of authoritarianism increases in small island settings, which can be observed in a number of autocratic and personalistic microstate rulers within the democratic microstate political system. Thus, political reality often diverges from the political institutions. Veenendaal (2013) elaborated on two reasons that may ground the phenomenon: the absence of varying interests and cleavages may create a lack of ideological competition, namely who is more important than what and how whenever there is a political rivalry. On the other hand, because voters often know political figures personally, their personal relations rather than their substantive political attitudes guide their voting behaviour. Furthermore, it has been found that smallness stimulates the prevalence of personalistic over programmatic forms of political competition due to closeness between citizens and politicians, the prevalence of multiple role relations, and attitudinal homogeneity. Island states often have competing political parties that appear to represent diverging socioeconomic interests. On closer inspection, however, the contests are based on personal rather than ideological premises. 
In fact, Macau largely proved the theoretical predictions of island scholars and now resembles other island microstates. Take, for instance, Edmund Ho, who was elected as a lawmaker prior to Macau's handover when he was a young man just returning from Canada because his father Ho Yin was a well-respected leader in the Macau Chinese community who participated in extensive charity work benefiting local residents. Despite doubts about Edmund Ho's governance abilities, political experience and even personal integrity, he was elected with a large majority of the votes as the first Chief Executive of the Macau SAR. The current Chief Executive Chui Sai On is a similar case, i.e., he was elected with a majority of the votes despite alleged scandals reported in overseas media. However, the 2013 election marked a significant change, as new voters cared more about the candidates' platforms, personal abilities and past record. Some candidates supported by well-connected and powerful local families were surprisingly not elected, while some dynamic newcomers without connected backgrounds received thousands of votes. This interesting phenomenon, however, does not substantially oppose the findings from previous urban island studies, as Macau has certain distinct features due to its post-colonial economic boom.

1) To stimulate the local economy, immigration via investment and professional schemes was introduced shortly after the handover. Between 2000 and 2005, over 10,000 wealthy families settled in Macau for real estate investments, and each year over 1,000 professionals become Macau citizens based on their professional abilities. The new immigrants are confident, wealthy, well educated, and cosmopolitan. In particular, most of them possess foreign country residency and have little local attachment. They are conscious about human rights and confident in their political judgment, and they do not care about the complicated inter-personal relationships on the small island. The fact that the number of voters almost doubled in the 2013 election in comparison to 2001 reflected the dramatic change in the makeup of the population of the island city.

2) Higher education has progressed at a rapid pace, such that the percentage of Macau citizens with higher education more than doubled to $26 \%$ in comparison to 1999 . The eight universities in Macau are dominated by western-oriented non-local scholars, and students are taught science and democracy. Overall, young people in the wealthy island city are more exposed to the outside world and they are more open-minded.

In 2014, a "golden handshake" bill granting generous retirement benefits to top government officials brought thousands into the streets and resulted in Macau's largest street protest since the handover, with an estimated 20,000 people involved. The protestors complained that the welfare package was on the one hand far more generous than acceptable and on the other hand that the bill was passed without appropriate consultation and gauging of public opinion. Through their actions, the protestors showed the leading politicians that they did not represent the interests of Macau citizens and that the Legislative Assembly did not take seriously its responsibility to supervise the government. The protest escalated, as more than 7,000 protesters besieged the Legislative Assembly to demand the government to withdraw the bill. The legislators subsequently were forced to cancel the vote. At that time, Chui Sai On had just expressed his wish to serve another term as Macau's Chief Executive when his five-year 
tenure ends. However, the protest is likely to have affected his chances of re-election. Finally, he was forced to withdraw the bill. This event has been considered a turning point for Macau polity, as the masses began to seriously care about local public affairs.

\section{Social group system and consensus politics}

Ideally, the political systems of microstates should be characterized by competition for political positions and the enfranchisement of virtually all adult citizens. In reality, however, informal and consensus politics, which undermine the twin dimensions of contestation and inclusiveness, dominate island city culture. This is exactly the case for Macau. Ott (2000) noted that small-scale social structures are personalistic and informal; the overall pattern of social interaction is more cooperative, and thus small social systems mitigate political conflict and encourage elite cooperation, which increases the stakes for citizens. Such a system allows them to avoid getting involved in warfare and hence fosters a sheltered climate that is conducive to democratic politics. Being more ethnically and linguistically homogenous, small social systems exhibit characteristics that tend to favor the maintenance of democracy (Clague, Gleason and Kanck, 2001). Despite a number of virtues, informal politics can also show its downside in small island settings, particularly in terms of practicing democracy, which is evident in the island city of Macau.

\section{Social group system}

As a colonial executive under the direct control of Portugal, Macau's colonial government did not appropriately respond to the demands of Macau locals, and an obvious communication gap existed between the government and the Chinese masses. In fact, Portuguese, the sole official language before 1990, was neither spoken nor understood by most Macau citizens. Constrained by the language barrier, the Portuguese rulers had to rely on the Macanese, who are bi-lingual, to communicate with the Macau Chinese (Chan, 2003). Although Macanese served as intermediaries between the continental Portuguese and the Macau Chinese, the Macanese who occupied the middle and low echelons of the government bureaucracy were considered to be a privileged group that was detached from public opinion, and they were therefore resented by the Chinese community.

Most of the continental Portuguese who controlled governmental power barely understood the Macau Chinese; thus, ordinary local Chinese were in effect excluded from any role in policy making or public administration. The insufficient or even minimal communication between the rulers and the ruled left the Macau Chinese alienated from local politics, which negatively affected the efficient implementation of public policies and created deep distrust between the government and the public. Violent demonstrations by local Chinese against the Portuguese expatriate government in 1966 reflected the serious consequences of the communication gap between the Portuguese administration and the Macau people and the latter's hatred of the former. After these riots, to maintain the smooth operation of the enclave, the Portuguese rulers and Chinese community elites cultivated a unique system of consensus politics that was accompanied by a social association system to act as an effective institution for Chinese residents to articulate their interests (Kaeding, 2010).

Beijing controlled the Chinese-dominated social groups, such as the Chinese Chamber of Commerce, the trade unions, neighbourhood associations and teachers' unions, and it exerted enormous influence on Macau's political life for almost two years following 1966 riots. Distrusting the foreign power, Macau's citizens sought patronage from the Beijing-controlled 
social groups to protect their interests. As Beijing played an essential role in organizing the local social groups, pro-Beijing forces were firmly established and became dominant. A unique social association system emerged whereby Beijing's influence spread to each and every corner of Macau society. The social services offered by the pro-Beijing trade unions and neighbourhood associations gained popularity, and local residents developed a positive perception of the pro-Beijing forces because they worked for the people's rights and needs (Leung, 1999).

The number and types of local Chinese social groups began to expand in the 1980s, and many of these organizations explicitly represented the interests of Beijing. Many local Chinese commercial elites played leading roles at the core of these social groups. Since then, Macau's social groups have played much more important and wider roles than is found in other countries. In western democracies, social groups are normally formed by citizens to protect their and their constituencies' rights and interests and to channel their opinions to the government (Chou, 2005). In the colonial period, the Macau Chinese social groups tried hard to bridge the communication gap between Portuguese expatriates and the Chinese masses, who were largely excluded from decision making and public administration (Lai, 2008).

As Macau's Beijing-controlled social groups took responsibility for perpetuating Beijing's influence in a country occupied by a foreign nation, the social association system actually acted as the main vehicle to facilitate communication between the Portuguese Macau and Chinese central government. In effect, the joint management of Portuguese expatriates and local Chinese community leaders in the island city largely helped to reduce anti-colonialist sentiment among the Macau Chinese. The Portuguese governor and his policy secretaries were accustomed to reaching consensus with the Chinese community leaders before proposing draft laws for discussion and approval. Because the political assets and economic prowess of the pro-labour groups were rather weak in comparison to those of the business elites, the Macau government predominantly cooperated with the pro-business groups, whose development helped to enhance their own legitimacy and their relationships with China (Yee, 2005). The dominant pro-Beijing Chinese community leaders also refrained from being too critical of the colonial government. Pro-China lawmakers seldom criticized the performance and activities of the Portuguese administration. The cooperation of the Macau Chinese community leaders helped the Portuguese govern Macau relatively smoothly until the mid-1990s. In fact, this type of consensus politics restricted public policy decisions to a small number of powerful Portuguese and Chinese elites, who had little professional knowledge to execute efficient public policies. Formal institutions such as those in western democracies through which citizens could express their demands and needs to the government's leaders were neither adequate nor popular (Lo, 1989).

\section{Consensus politics in crisis}

Sutton and Payne (1993) noted that public officials in small settings often meet each other outside the public sphere, such that formal institutions are often ignored. The formal institutional structure of island states often presents a misleading picture of the more substantive and practical nature of microstate politics, i.e., superficially democratic but in reality personalistic. Because they in effect decided on most of the deputies, the colonial government and the Chinese social groups dominated local politics, often by reaching an initial consensus under the table. While a main task of informal institutions in a democracy is 
to modify, supplement, or extend the formal institutions, informal rules and practices in Macau took precedence over procedural norms to realize political goals. The formal rules indeed only served as a cover for the informal practices.

Informal communications between the Chinese business elites and the Macau SAR government often precede legitimate public policies made by the formal institutions. Furthermore, the informal political interactions among social groups are neither restricted nor suppressed by the formal institutions. In fact, the dominance of the informal political practice largely occurs because of the deficiency of the formal institutions in the island city of Macau (Yu, 2007). Anckar (2010) argued that small islands make citizens more capable of orienting themselves toward political life and organization, and they also promote open channels of communication between ordinary citizens and the top leaders. Macau's limited size and space have made personal interactions rather than formal rules and regulations the dominant means of political interaction between institutions and social groups. This close connection has helped to establish smooth society-state relations since the handover by fostering informal interactions between the SAR government and community leaders. However, as the working relationships are based on cooptation and cooperation, this type of harmony also restricts the government's autonomy from powerful business elites with regard to decision making. In an in-depth study of the African microstate of Sao Tome and Principe, Seibert (2013) highlighted the fact that personalistic ties between citizens and politicians can impede neutral and impartial decision making. In addition, as a result of ubiquitous patronage, the civil service of this African island state is filled with government supporters. In fact, the dominance of informal practice over formal institutions does not enhance but corrupts the democratization of Macau because social groups do not have to facilitate mass political participation in the regular way. They are barely the political capital of the business elites for political bargaining aimed at their own interests.

In a dialectical sense, however, the informal political communication and interaction in Macau have had some positive impacts. For example, informal practice can remedy the deficiencies of malfunctioning formal establishments in balancing the interests of different social groups without becoming involved in complicated procedures and can make communication between social groups less time-consuming. Informal institutions deeply represent the political culture of the island city of Macau, which pursues social harmony and non-confrontational relations, even though such relations are largely superficial. In fact, the SAR government has used informal institutions to advocate social harmony and to suppress the various political pursuits to pluralize Macau's polity. As informal practice is the real actor behind the formal political establishments, politics have generally been hidden from checks by the public (Yu, 2007). In fact, the overreliance on informal practice is unlikely to guarantee the efficient governance of the SAR in the long run in a dynamic and ever-changing environment.

As their role in bridging the gap between the Chinese masses and the Portuguese colonial government ended with the emergence of the SAR government, the Macau Chinese community leaders were asked by the Chinese central government to lead the government and take the blame for its failures. Thus, the relationship between the pro-Beijing forces and the new SAR government dominated by local business elites has been considered to be both cooperative and tense. Because of their political stance, the pro-Beijing social groups, which were once considered the conscience of society and the voice in the wilderness, are now obliged to support the SAR government (Yeung, Lee and Kee, 2008). However, collusion between the government and the pro-Beijing social groups seems to be inevitable, particularly 
in terms of worker and social policies. Furthermore, because the casino sector rose to become the island city's dominant branch and by far the largest employer, the increasing power of the big players in Macau's economy has resulted in a deep divide between the casino moguls and ordinary gaming sector employees.

Most of the ordinary citizens in Macau are not really happy with the pro-Beijing social groups, whose mandates in the Legislative Assembly rarely express critical opinions on government policies. The fact that the pro-Beijing groups lost huge numbers of votes in the 2005 and 2009 Legislative Assembly elections reflected the deep disappointment of Macau's people about their performance and their loss of influence in the post-colonial era. Although the business elites managed to retain most of their mandates in the legislature, they did poorly and lost their dominance in law making. In contrast, independent pro-democratic social groups became the biggest winner, and more importantly, they seem to have won the support of people from different social strata and ethnic backgrounds. The pro-government orientation of the traditional social groups deterred them from taking legitimate responsibility to check government power. Because it is difficult for these groups to reconcile their double role as government policy interpreter and supervisor, and they often had to oppose interests of their members, the social groups became targets of blame. While the traditional social groups have become pro-establishment and less vocal, the aggressive approach of some of the newly formed social groups has attracted a sizeable portion of the population, particularly Macau's youth (Sheng, 2012).

Baker (1992) noted that conflicts of interest and personalized politics are inevitable in small states, as blurred boundaries between official and personal roles is the only practical way of doing business in small settings. In other words, manipulation and mobilization of the masses can be easily performed by the elite, while at the same time, corruption also seems to be inevitable. Indeed, corruption scandals have accompanied the SAR throughout its short history. The exposure of the corruption case of the former Policy Secretary for Transport and Public Construction, which involved approximately US\$100m, confirmed a suspicion that had been circulating widely. A similar dubious case that outraged the public involved more than $50 \%$ in government overspending on facilities that were designed for the 4th East Asian Games (Sheng and Tsui, 2009b). Groups and businessmen who are close to the government always seem to be selected to run government projects, and the government is also often accused of favoring foreign investors, who bribe government officers.

Dahl and Tufte (1973) found that political conflicts are less likely to occur in small islands, but when they arise, group conflicts can be expected to be more personal, more explosive, and more polarized between every part of the society. This is what exactly happened in the island city of Macau. In the May 2007 protest, thousands of jobless local workers became violent. They blamed the Chief Executive Edmund Ho of "betraying neighbours' interests to foreign capitalists and guest workers" and attacked Ho's family members when they gathered to mourn Ho's brother. When the current Chief Executive Chui Sai An approved the "Golden Handshake" bill in 2014, 20,000 Macau people demonstrated against him personally, drew pictures of him as a pig that makes himself rich, and asked him to resign. Veenendaal (2015) found that due to the increased social intimacy in small settings, political decision making unavoidably interferes with interpersonal relationships. The fact that Macau citizens from different social classes often blame the Chief Executives personally and become violent shows that interpersonal conflicts can be more emotional and enduring than 
rivalries over political ideas. In fact, a series of protests in the island city of Macau all seem directly aimed at its top leaders because the demonstrators know the leading politicians personally. They expect politicians to take care of their "neighbours"; but, when they do not, the masses become extremely angry.

\section{Conclusion}

The evolution of political culture in the Macau SAR reflects a society undergoing a postcolonial transformation. Although the island city has a number of Western-style formal democratic institutions, the ethics and political culture within the administrative system remain largely traditional, conservative and informal. Behind the seemingly democratic polity lies a more traditional practice of informal politics amid a distorted electoral contest that represents nepotism, autocracy and strong inertia to not be democratic. Furthermore, Macau continues to face the dilemma whereby informal practice has helped to maintain a superficial social harmony and smooth policy implementation, but imprecise and inefficient formal institutions and regulations and over-dependence on somewhat corrupt informal institutions have begun to undermine the legitimacy of the SAR government.

Macau as an island city is particularly useful for scholarly purposes because it can be easily conceptualized as a distinct unit, as a place for which special governance solutions may be appropriate. While the experiences in some small island communities demonstrate that micro-level governance can be both powerful and democratic in function without maintaining liberal democratic institutions, the case of Macau shows that although the dominance of informal politics over formal politics within a democratic structure facilitates efficient decision making and smooth policy implementation via consensus politics, it ultimately may cause social discontent and political instability because of the strong inertia of informal politics to be corrupt. As a booming "world class tourism and leisure centre" with a massive inflow of immigrants, the conventional wisdom of liberal democracy over alternative forms of government seems to be appropriate for the long-run prosperity of the island city of Macau.

\section{References}

Anckar, D. (2006). Islandness or smallness? A comparative look at political institutions in small island states. Island Studies Journal, 1(1), 43-54.

Anckar, D. (2010). Small is democratic, but who is small? Arts and Social Sciences Journal, 2, $1-10$.

Baker, R. A. (1992). Scale and administrative performance: the governance of small and microstates. In R. A. Baker (Ed.), Public administration in small and island states (pp. 5-25). West Hartford CT: Kumarian Press.

Baldacchino, G. (2012). Islands and despots. Commonwealth \& Comparative Politics, 50(1), 103-120.

Chan, M.K. (2003). Different roads to home: the retrocession of Hong Kong and Macau to Chinese sovereignty. Journal of Contemporary China, 12(36), 493-518.

Chong, C.C. (2015). Probe into the issue of interpretation of the Basic Laws. Academic Journal of One Country Two Systems, 4, 143-157.

Chong, C.C., \& Chan, W.T. (2012). On the improvement of the indirect election system for the Legislative Assembly of the Macao SAR. Academic Journal of One Country Two Systems, 2, 139-151. 
Chou, K.P. (2005). Interest group politics in Macau after handover. Journal of Contemporary China, 14(43), 191-206.

Clague, C., Gleason, S., \& Kanck, S. (2001). Determinants of lasting democracy in poor Countries: culture, development, and institutions. Annals of the American Academy of Political and Social Science, 573, 16-41.

Dahl, R.A., \& Tufte, E.R. (1973). Size and democracy. Redwood City CA: Stanford University Press.

De Pina-Cabral, J., \& Lourenco N. (1994). Personal identity and ethnic ambiguity: naming practices among the Eurasians of Macao. Social Anthropology. 2(2), 115-132.

Grydehøj, A. (2015). Island city formation and urban island studies. Area, 47(4), 429-435.

Grydehøj, A. (2016). Toward subnational democracies of scale: tensions between democratic legitimacy, legality, and effective governance. Geopolitics, 21(1), 22-42.

Ho, C.S. (2015). Governance, inclusion and trust in Singapore, Hong Kong and Macao. Asian Education and Development Studies, 4(3), 250-264.

Huang, Q.C. (1999). General history of Macau. Guangzhou: Guangdong Education Publishing House.

Kaeding, M.P. (2010). The evolution of Macao's identity: Toward ethno-cultural and civicbased development. The Journal of Comparative Asian Development, 9(1), 133-168.

Ke, C.X., Konrad, K. \& Morath, F. (2013). Brothers in arms: an experiment on the alliance puzzle. Games and Economic Behaviour, 77(1), 61-76.

Lai, W.L. (2008). The regulatory role of social policy: Macao's social security development. Journal of Contemporary Asia, 38(3), 373-394.

Lai, W.L. (2010). The political economy of social security development in Macao. China Journal of Social Work, 3(1), 65-81.

Lau, T. (2002). A study on gambling industry in Macau. Hong Kong: SDX Joint Publishing Company.

Leng, T.X. (2011). On the fundamental characteristics of the 'One Country, Two Systems' policy. Academic Journal of One Country Two Systems, 1, 49-59.

Leung, B. (1999). Has the Chinese focus on Hong Kong led to the neglect of Macau? Asian Affairs, 26(1), 11-25.

Lo, S.H. (1989). Aspects of political development in Macao. The China Quarterly, 120, 837851.

Lo, S.H., \& Chong, K.M. (2016). Casino interests, Fujian Tongxianghui and electoral politics in Macao. Journal of Contemporary Asia, 46(2), 286-303.

Lo, S.H., \& Yee, H. (2005). Legitimacy building in the Macau SAR: colonial legacies and reform strategies. Asian Journal of Political Science, 13(1), 51-79.

Macao Statistics and Census Services (2015) Yearbook of Statistics 2015. Macau: Macao Statistics and Census Services.

Ott, D. (2000). Small is democratic: An examination of state size and democratic development. Hove: Psychology Press.

Sheng, L. (2011a). Foreign investment and urban development: a perspective from tourist cities. Habitat International, 35(1), 111-117.

Sheng, L. (2011b). Regional competition and sustainable development: a game theory model for tourism destinations. European Planning Studies, 19(4), 669-681. 
Sheng, L. (2012). Rethinking the impacts of foreign investors on urban development: the city of Macao. Annals of Regional Science, 49(1), 73-86.

Sheng, L. (2014). Effects of foreign expansion on local growth: the case of Macao. European Planning Studies, 22(8), 1735-1743.

Sheng, L., \& Tsui, Y.M. (2009a). A general equilibrium approach to tourism and welfare: the case of Macao. Habitat International, 33(4), 419-424.

Sheng, L., \& Tsui, Y.M. (2009b). Casino booms and local politics: the city of Macau. Cities, 26(2), 67-73.

Sheng, L., \& Zhao, W.B. (2016). Strategic destination management in the face of foreign competition: the case of Macao SAR. Journal of Travel \& Tourism Marketing, 33(2), 263-278.

Seibert, G. (2013). São Tomé and Príncipe: The first plantation economy in the tropics. In R. Law, S. Schwarz, \& S. Strickrodt (Eds.), Commercial agriculture, the slave trade and slavery in Atlantic Africa (pp. 54-78). Oxford: James Currey.

Song, X.X. (2015). A comparative study on the relations of the executive to the legislature and the judiciary in the Hong Kong SAR and the Macao SAR. Academic Journal of One Country Two Systems, 3, 119-132.

Steyn, G. (2015). The impacts of islandness on the urbanism and architecture of Mombasa. Urban Island Studies, 1, 55-80.

Sutton, P., \& Payne, A. (1993). Lilliput under threat: The security problems of small island and enclave developing states. Political Studies, 41(4), 579-593.

Veenendaal, W. (2013). Size and personalistic politics: characteristics of political competition in four microstates. The Round Table, 102(3), 245-257.

Veenendaal, W.P. (2015). Democracy in microstates: why smallness does not produce a democratic political system. Democratization, 22(1), 92-112.

Wu, Z.L. (2009). The establishment of Macao as a special port city and ensuing debates. Social Sciences in China, 30(2), 116-133.

$\mathrm{Xu}, \mathrm{C}$. (2013). A study on the question of Portuguese as an official language. Academic Journal of One Country Two Systems, 3, 132-142.

Yee, H. (2005). The 2001 Legislative Assembly elections and political development in Macau. Journal of Contemporary China, 14(43), 225-246.

Yeung, Y.M., Lee, J., \& Kee, G. (2008). Hong Kong and Macao under Chinese sovereignty. Eurasian Geography and Economics, 49(3), 304-325.

$\mathrm{Yu}$, W.Y. (2007). Formal and informal politics in Macao Special Administrative Region elections 2004-2005. Journal of Contemporary China, 16(52), 417-441.

Zhao, G.Q. (2011). Reflections on several issues relating to law reform. Academic Journal of One Country Two Systems, 1, 103-111. 